\title{
Inhibitory Effect of Chitosan and Phosphate Cross-linked Chitosan against Cucumber Mosaic Virus and Pepper Mild Mottle Virus
}

\author{
Venkata Subba Reddy Gangireddygari ${ }^{\mathbf{1}}$, Bong Nam Chung ${ }^{\mathbf{1}}$, In-Sook Cho ${ }^{\mathbf{1}}$, and Ju-Yeon Yoon (1) 1,2* \\ ${ }^{I}$ Virology Unit, Horticulture and Herbal Crop Environment Division, National Institute of Horticulture and Herbal \\ Science, Rural Development Administration, Wanju 55365, Korea \\ ${ }^{2}$ Graduate School on Plant Protection and Quarantine, Jeonbuk National University, Jeonju 54896, Korea
}

(Received on October 27, 2021; Revised on November 13, 2021; Accepted on November 15, 2021)

Cucumber mosaic virus (CMV) and Pepper mild motthe virus (PMMoV) causes severe economic loss in crop productivity of both agriculture and horticulture crops in Korea. The previous surveys showed that naturally available biopolymer material - chitosan (CS), which is from shrimp cells, reduced CMV accumulation on pepper. To improve the antiviral activity of CS, it was synthesized to form phosphate cross-linked chitosan (PCS) and compared with the original CS. Initially, the activity of CS and PCS $(0.01 \%, 0.05 \%$, and $0.1 \%$ concentration) compound against $\mathrm{PMMoV}$ infection and replication was tested using a half-leaf assay on Nicotiana glutinosa leaves. The total number of local lesions represented on a leaf of $N$. glutinosa were counted and analyzed with phosphate buffer treated leaves as a negative control. The leaves treated with a $0.1 \%$ concentration of CS or PCS compounds exhibited an inhibition effect by $40-75 \%$ compared with the control leaves. The same treatment significantly reduced about $40 \%$ CMV accumulation measured by double antibody sandwich enzyme-linked immunosorbent assay and increased the relative expression levels of the $N P R 1, P R-1$, cysteine

*Corresponding author.

Phone) +82-63-270-4188

E-mail) juyeon74@gmail.com

ORCID

Ju-Yeon Yoon

https://orcid.org/0000-0003-1646-7310

Handling Editor : Rae-dong Jeong

(c) This is an Open Access article distributed under the terms of the Creative Commons Attribution Non-Commercial License (http:// creativecommons.org/licenses/by-nc/4.0) which permits unrestricted noncommercial use, distribution, and reproduction in any medium, provided the original work is properly cited.

Articles can be freely viewed online at www.ppjonline.org. protease inhibitor gene, $L O X, P A L, S R C 2, C R F 3$ and $E R F 4$ genes analyzed by quantitative reverse transcriptase-polymerase chain reaction, in chili pepper plants.

Keywords : chili pepper, chitosan, DAS-ELISA, phosphate cross-linked chitosan, RT-qPCR

Chili pepper is the most important vegetable and spice crop because of its unique characteristics of color, taste, pungency, flavor and aroma in worldwide (Rohini and Lakshmanan, 2017). In 2020, chili pepper was produced 60,076 tons in South Korea (Statistics Korea, 2020). Chili productivity was decreased by 18,361 tons $(23.4 \%)$ with the value of 78,347 tons of pepper as per the 2019 data. Among the pepper infecting viruses, the cucumber mosaic virus (CMV) is devastating in both agriculture and horticulture crops in the world (Elsharkawy et al., 2012). CMV is a type species of the genus Cucumovirus, in the family Bromoviridae and it has a wide host range of more than 1,071 species belonging to 521 genera from 100 families and is transmitted by 80 species of aphids (Palukaitis and García-Arenal, 2003; Yoon et al., 2019). CMV in chili pepper is the most widespread virus in South Korea (Cho et al., 2007; Choi et al., 2005; Kwon et al., 2018; Lee et al., 2015), severe symptoms were attributed to CMV infection such as mosaic, stunting growth, distortion and a characteristic shoestring like leaf appearance (Sudhakar et al., 2007). Pepper mild mottle virus (PMMoV) is also one of the major viruses in pepper species (Capsicum spp.) in the world (Adams et al., 2009). PMMoV is a single-stranded positive-sense RNA virus classified in the genus Tobamovirus, which includes viruses extremely resistant to physical and chemical agents (Anonymous, 2006; Wetter et al., 1984). PMMoV infection initially causes mild foliar mosaic symptoms followed 
by mottling and malformation of leaves and fruits, resulting in significant losses of pepper yield and cash values (Kim et al., 2012). To reduce the viral disease incidence, agrochemicals such as pesticides are indispensable tools to a boon in agriculture production (Qin et al., 2011; Voss-Fels and Snowdon, 2016). But these agrochemicals are a serious threat to the biogeochemical cycling of the entire biosphere (Damalas and Koutroubas 2016). At the point of a healthy biosphere environment, other alternative methods need to be explored.

Chitin is the second most abundant natural biopolymer after cellulose and it is a semi-crystalline homopolymer of $\beta$ - $(1 \rightarrow 4)$-linked N-acetyl-D-glucosamine units. Chitosan (CS) is extracted from the chitin by the deacetylation process, it is the major component of the fungal cell wall and the arthropod exoskeleton (Iriti and Varoni, 2015). CS is a heteropolysaccharide composed of $\mathrm{N}$-acetyl D-glucosamine and D-glucosamine by $\beta-(1 \rightarrow 4)$ glycosidic bonds (Iriti and Varoni, 2015). CS is a biodegradable, non-toxic compound, with antimicrobial nature (Kumaraswamy et al., 2018) by electrostatic interactions and also induced plant defense mechanism to pathogens by systemic acquired resistance (SAR) (Xing et al., 2015). CS has been reported in various applications in the agriculture and horticulture commodities, including plant growth promotion, protecting food products from different pathogens, and inducing tolerance in biotic and abiotic stress and post-harvest technology (Lustriane et al., 2018; Malerba and Cerana, 2016; Pratiwi et al., 2015; Shahrajabian et al., 2021; Yin and Du, 2010).

There are some reports were reported on the CS application promotes plant growth promotion (Kumaraswamy et al., 2018; Sharif et al., 2018); and also act as delivery of agrochemicals, fertilizers, micronutrients as well as genetic materials in the form of CS nanoparticles (Malerba and Cerana, 2016). Liu et al. (2004) reported that CS has shown antimicrobial activity for bacteria, yeast, and molds. CS is also used as a conventional fungicide in both preharvest (Feliziani et al., 2015) and post-harvest applications (Sivakumar et al., 2016; Zhang et al., 2015). CS applicationinduced response against potato virus $\mathrm{X}$ and tomato mosaic virus was reported by (Chirkov et al., 2001; Jia et al., 2016; Nagorskaya et al., 2014). CS perception in the plant's variation in the ion fluxes and membrane depolarization (Iriti and Varoni, 2015) and also recognized by the plant as a pathogen-mimicking stimulus, but the identification of a CS receptor is still mysterious (Malerba and Cerana, 2016; Povero et al., 2011). Although Petutschnig et al. (2010) found that the chitin elicitor receptor kinase 1 (CERK1) also bound weakly to CS, later Povero et al. (2011) dem- onstrated that the perception of CS was independent of CERK1. Recently, Liu et al. (2018) suggested wheat W5G2U8, W5HY42, and W5I0R4 as potential CS oligosaccharides receptors. However, the detailed mechanism of action of CS in reducing plant diseases has not been completely revealed (Hassan and Chang, 2017).

There is a piece of scanty information that has been available on the mechanism of controlling the viral diseases in chili pepper with not only CS, but also phosphate crosslinked chitosan (PCS). Therefore, the study has been aimed at understanding the resistant mechanism by CMV in chili pepper treated with CS or PCS.

\section{Materials and Methods}

Virus source. CMV-GTN was maintained in Nicotiana tabacum leaves and confirmed virus viability by the immunostrip method (Choi et al., 2015). Infected leaves were collected aseptically and ground with $0.01 \mathrm{M}$ phosphate buffer ( $\mathrm{pH}$ 7.0) using a sterilized plastic pouch in the ratio of $1 \mathrm{~g}$ leaf tissue per $10 \mathrm{ml}$ of the buffer. The suspension is used as the source of inoculum for chili pepper infection. The first two true leaves of each chili pepper plant were lightly dusted with carborundum (Thermo Fisher Scientific, Waltham, MA, USA) and then rubbed with inoculum from leaf base to tip, contains CMV-infected tobacco leaf suspension. All the plants including the controls were inoculated with CMV.

Preparation of CS and PCS solution. CS flakes (MW 600,000 ; viscosity $50-800 \mathrm{mPa}$, degree of deacetylation 80 95\%) was purchased from Kwang Jin Chemical Co. Ltd., Siheung, Korea. To prepare a $2 \%$ CS solution, the required amount of CS flakes was dispersed in pre-prepared $2 \%$ acetic acid, with stirring for $12 \mathrm{~h}$ at a uniform temperature of $60^{\circ} \mathrm{C}$. The obtained CS solution was cooled to room temperature. The structure of CS is represented in Supplementary Fig. 1A. For the synthesis of PCS, each CS and ammonium polyphosphate solution were placed over a heat bath with stirring at $600 \mathrm{rpm}$, and the temperature was gradually increased from room temperature to $80^{\circ} \mathrm{C}$. Under these conditions, the reaction was allowed to continue for $12 \mathrm{~h}$. After completion of the reaction, the contents of the flask were cooled to room temperature, and then vacuum filtered. The obtained pale yellow product was thoroughly washed with deionized water, dried in an oven at $70^{\circ} \mathrm{C}$ for $24 \mathrm{~h}$, and ground into powder. Finally, a distinct paleyellow powder of a novel compound based on CS and ammonium polyphosphate was obtained. Hereafter, the compound is referred to as PCS. This synthesis mechanism was 


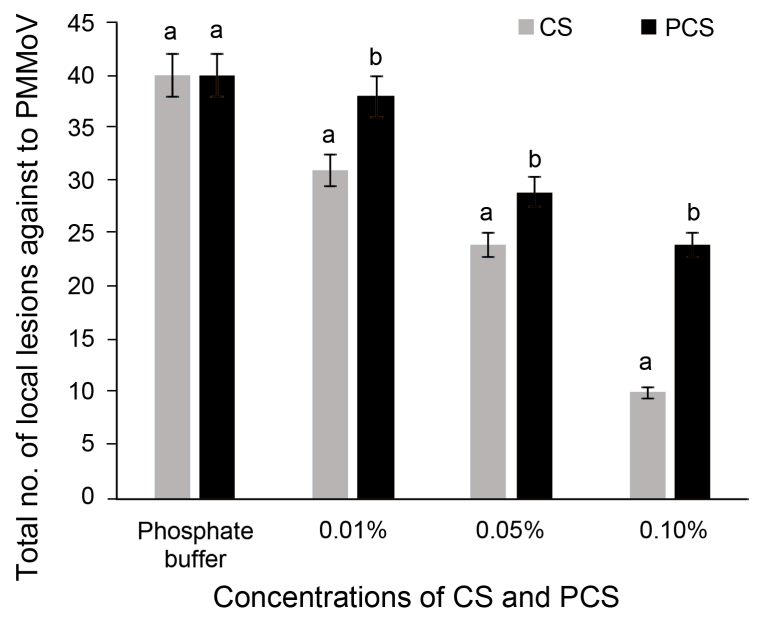

Fig. 1. Antiviral activity chitosan (CS) and phosphate crosslinked chitosan (PCS) by hypersensitive response. PMMoV, pepper mild mottle virus.

depicted in Supplementary Fig. 1B. To prepare a 2\% stock solution of CS or PCS, the required amount of CS or PCS powder was dispersed in pre-prepared $2 \%$ acetic acid, with stirring. Stirring was continued for $12 \mathrm{~h}$ at a uniform temperature of $60^{\circ} \mathrm{C}$ to obtain a homogeneous solution of CS or PCS and cooled to room temperature. The stock solution of CS or PCS was diluted to $0.01 \%, 0.05 \%$, and $0.1 \%$.

Local lesion count assay. Infectious PMMoV was quantified by a local lesion count assay with $N$. glutinosa. The seed and the seedling of $N$. glutinosa were grown and cultured in the soil pot. After cultivation, three leaves of each plant were painted with at the concentrations of $0.01 \%$, $0.05 \%$, and $0.1 \%$ of CS, and PCS materials once a day for three times, then covered with 600 mesh carborundum, and then PMMoV inoculums in $0.01 \mathrm{M}$ phosphate-buffered saline was rubbed into each leaf with a gloved finger. After washing, the plant was incubated in the growth chamber at $25^{\circ} \mathrm{C}$ under a long-day photoperiod (16-h light, 8-h dark) for 4-5 days. At the end of the incubation, local lesions on each leaf were counted, and the average lesion count prepared from a single sample was considered as the infectious PMMoV concentration for that sample. The number of local lesions was compared with the control local lesions.

Pot experiment. The efficacy of antiviral agents in controlling CMV in chili pepper was assessed under greenhouse conditions. Chili pepper plants at a four-leaf stage were selected for spraying of CS and PCS at the concentrations of $0.01 \%, 0.05 \%$, and $0.1 \%$ once a day for three days, then followed by CMV-GTN inoculation. Foliar spray with dis- tilled water was carried out as the control treatment.

Double antibody sandwich enzyme-linked immunosorbent assay. Double antibody sandwich enzyme-linked immunosorbent assay (Vitti et al., 2016) was used for the rapid detection of the virus as per the manufacturer's protocol (Agdia, Elkhart, IN, USA). The experimental setup chili pepper seedlings upper leaf sample was collected at 2 weeks of post-inoculation (wpi) along with control samples and extracts the CMV antigen by using a general extraction buffer. The extracted samples of $(100 \mu l)$ were analyzed after performing several steps in the protocol. The absorbance value of each sample was measured at $405 \mathrm{~nm}$ by an ELISA reader (Titertek, Huntsville, AI, USA) thirty minutes after the addition of $100 \mu \mathrm{l}$ of the substrate ( $p$-nitrophenyl phosphate at $1 \mathrm{mg} / \mathrm{ml}$ in $10 \%$ of diethanolamine $\mathrm{pH}$ 9.8). A sample was noted as positive if the OD exceeds 3 times the mean of the negative controls (Yoon et al., 2021).

Quantitative real-time PCR analysis. Quantitative realtime PCR (RT-qPCR) analysis was performed on chili pepper plants, which were sprayed with CS, PCS of $0.1 \%$, and water (i.e., control). Leaf tissues (consisting of three biological replicates) were collected, immediately frozen in liquid nitrogen, and stored at $-80^{\circ} \mathrm{C}$ until RNA extraction. Total RNA was isolated using the Plant RNA Prep Kit (BCS Plan RNA Prep kit, Biocube, Gwacheon, Korea). RNA quantity and quality were checked by using a nanodrop (Bio-Rad, Hercules, CA, USA). Only RNA with an A260/ A280 ratio $\geq 1.95$ was retained for subsequent analysis. The cDNA was synthesized using the SuperScript IVVILO cDNA synthesis kit (Invitrogen, Carlsbad, CA, USA) according to the manufacturer's instructions. RT-qPCR reactions were made to a final volume of $20 \mu \mathrm{l}$ contained $2 \mu \mathrm{l}$ of cDNA. The PCR cycling program was set as follows: initial denaturation at $95^{\circ} \mathrm{C}$ for $3 \mathrm{~min}$, then 40 cycles of denaturation at $95^{\circ} \mathrm{C}$ for $15 \mathrm{~s}$, and extension at $59^{\circ} \mathrm{C}$ for the $30 \mathrm{~s}$. The program was completed with melt curve determination from $60^{\circ} \mathrm{C}$ to $95^{\circ} \mathrm{C}$ with incremental steps of $0.5^{\circ} \mathrm{C}$ for $5 \mathrm{~s}$ (Bio-Rad). CS and PCS treated chili pepper plants defense genes - such as CaNPR-1, CaPR-1, CaPR4, Cysteine, defensin, lignin, CaLOX, CaPAL, CaSRC2, $C a C R F 3$, and CaERF4; were studied and quantified relative to the expression level of $C a U B Z$. All primer pairs were designed using Primer Select of the Primer Quest tool (Integrated DNA Technologies, Inc., Coralville, IW, USA). Primers' specificity in recognizing target genes in the chili genome was validated by sequencing the amplified fragments (170-200 bp). The primers used in this study are listed in Table 1. 
Table 1. Primers used for the RT-qPCR

\begin{tabular}{|c|c|c|c|}
\hline Acronym & Gene name & Accession no. & Primer sequence $\left(5^{\prime} \rightarrow 3^{\prime}\right)$ \\
\hline CaNPR1 & C. annuum regulatory protein NPR1 & NM_001325099 & $\begin{array}{l}\text { F: GGCTAGCATCAGGAAGAAGAT } \\
\text { R: CAGTTCTAGACAGCGCCATAAAG }\end{array}$ \\
\hline CaPR-1 & Pathogenesis-related protein 1 & AF053343 & $\begin{array}{l}\text { F: GCCCTATGACATGGGACAATAG } \\
\text { R: GGACGTTGTCCTCTCCAATTAC }\end{array}$ \\
\hline CaPR-4 & Pathogenesis-related protein 4 & JX030397 & $\begin{array}{l}\text { F: GAACGTGAGGTCAACATACCA } \\
\text { R: CATCCCAAGTAGCGCAGTAA }\end{array}$ \\
\hline Cystein & $\begin{array}{l}\text { Cysteine proteinase } \\
\text { Inhibitor 5-like }\end{array}$ & XM_016685030 & $\begin{array}{l}\text { F: GACATAAAGGACCCTGAAGTGG } \\
\text { R: CTCCAATACCGTCTTAGCCTC }\end{array}$ \\
\hline defensin & Flower defensing-like & XM_016724214 & $\begin{array}{l}\text { F: GGCTCGTTCCATTTACTTCATG } \\
\text { R: AGAACCTTGCATCCCATTAGC }\end{array}$ \\
\hline Lignin & Lignin forming anioinc peroxidase-like & NM_001324912 & $\begin{array}{l}\text { F: TCC CTC ATT CGC CTT CAT TTC } \\
\text { R: CAATGCCGTTTTCTCACTGAC }\end{array}$ \\
\hline CaLOX & 13-lipoxygenase & KC404864 & $\begin{array}{l}\text { F: GTTGGACATGGTGACAAGAAAG } \\
\text { R: TGAGCAGAAGCTACCCAAATTA }\end{array}$ \\
\hline CaPAL & Phenylalanine ammonia-lyase & XM_016699298 & $\begin{array}{l}\text { F: CTTGGTGGTGAAACATTGACAG } \\
\text { R: CAGCTCTTGCATCCTCAGATAA }\end{array}$ \\
\hline CaSRC2 & SRC2-like protein & NM_001324570 & $\begin{array}{l}\text { F: CCAGGGCTGTACCTTGTTATT } \\
\text { R: AGAAGTCTCCTGATTGAACATCTC }\end{array}$ \\
\hline CaCRF3 & $\begin{array}{l}\text { Ethylene-responsive transcription factor CRF3- } \\
\text { like }\end{array}$ & XM_016722295 & $\begin{array}{l}\text { F: CTCGACTTTGGTTGGGAACT } \\
\text { R: TTGGAGGTGGCTTGAGAATG }\end{array}$ \\
\hline CaERF4 & Ethylene-responsive transcription factor 4-like & XM_016716273 & $\begin{array}{l}\text { F: TGGCAGGTCCTCGTACTATT } \\
\text { R: CGATCAAGACCACCTCCATTAC }\end{array}$ \\
\hline $\mathrm{CaUbZ}$ & E3 ubiquitin-protein ligase & NM_001325074 & $\begin{array}{l}\text { F: TTCTTGAATGGTGCCAGAGG } \\
\text { R: AGATTGCGGTGTTTCTAGGAG }\end{array}$ \\
\hline
\end{tabular}

RT-qPCR, quantitative real-time PCR.

Statistical analysis. The data were compared using a oneway ANOVA analysis. All were tested at $P \leq 0.05$ significance level and the Duncan multiple range tests were used for separation between treatments. Statistica v.10, Statsoft was used for all statistical analyses.

\section{Results}

Antiviral efficacy. The application of CS and PCS at three different concentrations of local lesions count in N. glutinosa were analyzed (Fig. 1, Supplementary Fig. 2). The local lesions count on the leaves of $N$. glutinos a treated with phosphate buffer are more number compared with treatments of CS and PCS. The number of local lesions was inversely proposed to the concentrations of CS and PCS. The painting of CS and PCS at $0.1 \%$ decreased the PMMoV local lesions by $40-75 \%$ related to the control local lesion count. Overall the CS at $0.1 \%$ is best suitable for the control of PMMoV in N. glutinosa. Based on this hypersensitive response of CS and PCS materials concentrations were further tested by spraying at the concentrations of 0.01 ,
0.05 , and $0.1 \%$ in chili pepper infected with CMV.

For untreated chili pepper plants, symptoms of the disease appeared seven days after the infection and ranged

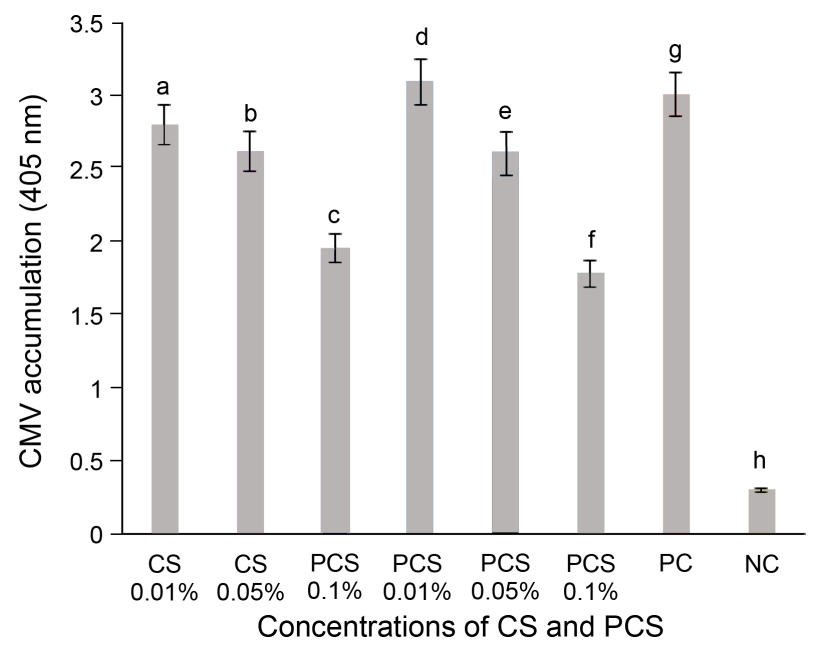

Fig. 2. Effect of chitosan (CS) and phosphate cross-linked chitosan (PCS) on cucumber mosaic virus (CMV) accumulation in chili pepper. $\mathrm{PC}$, positive control; $\mathrm{NC}$, negative control. 



Fig. 3. (A) Genes expression in chitosan (CS) and phosphate cross-linked chitosan (PCS) in chili pepper plants: $N P R 1, P R-1, P R-4$, cysteine protease inhibitor, lignin forming anion peroxidase, pepper defensin1. (B) PAL, LOX, SRC2, CRF3, ERF4 (ethylene response factor 4). Means of three replicates and standard errors are represented by bars. Significant differences $(P \leq 0.05)$ among treatments are indicated by different letters according to parameter of ANOVA One-way analysis.

from mild symptoms on new leaves to severe mosaic with stunting. However, chili pepper plants treated with CS and PCS by foliar spray showed an incredible reduction in CMV severity compared to the non-treated plants after 14 days of inoculation. Moreover, the reduction in the severity of CMV in chili plants by foliar spray treatment was higher than that of control-treated samples, ELISA test confirmed that CMV titer as an indicator for CMV accumulation was markedly reduced by $35-40 \%$ in chili pepper plants treated with CS and PCS at the concentrations of $0.05 \%$ and $0.1 \%$ in comparison to untreated plants after 2 weeks of virus inoculation (Supplementary Fig. 3). The results were ex- 
pressed in the graphical representation form (Fig. 2). CMV accumulation was much lower in chili pepper plants treated with $0.1 \%$ of CS and PCS as foliar spray relative to plants treated with distilled water as a control.

Induction of defense genes in chili pepper by CS or PCS. The induction of defense genes in chili pepper by foliar spraying of CS and PCS at $0.1 \%$ level was evaluated by RT-qPCR and the expression of CaNPR1, CaPR1, CaPR4, Cysteine, defensin, lignin, CaLOX, CaPAL, CaSRC2, $C a C R F 3$, and CaERF4 genes, were analyzed and shown (Fig. 3A). CS and PCS at $0.1 \%$ level the non-pathogenesis related proteins relative normalized expression is 3.8-fold and a 5-fold increase in the chili pepper in respective of CS and PCS compared with the control plants. In the same way, PR-1 expression is about 8-fold and 10-fold level increased in respective of CS and PCS. The chili pepper plants are relatively expressed a 2-fold level of cysteine, for both CS and PCS treatment. Whilst in the case of CaPR-4, lignin and defensin were more or less equal with the control plant's expression levels.

In addition to these genes, other genes were further assessed, analyzed, and presented (Fig. 3B). In the phenylalanine propanoid pathway phenylalanine ammonialyase (PAL) is a key enzyme to synthesize defense-related enzymes to express. The foliar spraying of CS and PCS at $0.1 \%$ level in chili pepper induced the expression of two oxidative genes - $\mathrm{CaPAL}$, CaLOX was normalized expression levels were 4.52, 4.01 and 3.62, 4.46 fold up-regulated in respective of CS and PCS correlated to the control chili pepper plants. To this gene product, we were further looked by foliar spraying of CS and PCS at $0.1 \%$ level in chili pepper, the genes such as - CaSRC-2, CaCRF-3 and $C a E R F-4$ and the results were set side by side with the buffer treated control and shown (Fig. 3B), the gene products CaSRC-2, CaCRF-3, and CaERF-4 were 72.93, 19.06, 3.63 and $41.56,16.40,1.66$ folds up-regulated to the CS and PCS treatments, respectively.

Based on the RT-qPCR study, we demonstrated that CS or PCS-treated chili pepper plants are stimulated in the expression of CaNPR-1, CaPR-1, CaPR-4, cysteine, defensin, lignin, $C a L O X, C a P A L, C a S R C 2, C a C R F 3$, and CaERF4 gene products. Overall the CS or PCS at $0.1 \%$ foliar spraying induced the expression of PR-1 proteins and other defense genes.

\section{Discussion}

CS and PCS were applied to chili plants as a foliar spray to induce defense-related genes. In the plant system, SAR is a long-lasting priming mechanism to many pathogenic infections (Mou et al., 2003), and also the plant responds to the production of reactive oxygen species (ROS), PR proteins, lignification and other cell wall structural proteins crosslinking (Pandey et al., 2017). Xing et al. (2015) reported that chitosan induced and enhanced the expression of defense-related enzymes, such as peroxidase, PAL, polyphenol oxidase, superoxide dismutase, and catalase.

In phenylpropanoid metabolism PAL is the key enzyme in the conversion of L-phenylalanine to ammonia and transcinnamic acid. Lee et al. (1994) demonstrated that multiple initiation sites in the PAL5 allow the tomato plant to respond to different environmental stimuli in a tissue-specific fashion. A recent study reveals a significant increase in the expression of PAL5 enzyme in tomato plants treated with $\mathrm{CS}$ alone and CS with CMV, compared to tomato plants treated with CMV only. These results are in agreement with the study of Mejía-Teniente et al. (2013), who treated Capsicum annum L., with CS. On the other hand, tobacco mosaic virus (TMV)-infected tobacco leaves increased $P A L A$ and $P A L B$ transcripts as well as PAL activity indicated that the phenylalanine pathway is the main route of salicylic acid (SA) synthesis. Compared to CMV-TP, the significantly higher PAL5 expression detected in CHTCMV-TP suggests the involvement of phenylpropanoidderived products as lignin and SA (Rendina et al., 2019). In our study also indicated that, increased the expression of PAL enzyme as to the control chili pepper plants. Not only $P A L$, and other defense-related genes are up-regulated in chili pepper by foliar application of both CS and PCS to the control (Fig. 3A and B).

$\mathrm{CS}$ and CS nanoparticle-treated tomato plants were enhanced in the expression of $P R 1, \beta-1,3$ glucanase, chitinase, $P R-1$ gene, and $P R-10$ defense-related genes were markedly higher than the control. The same materials were also increased in the expression of superoxide dismutase (SOD) and catalase (CAT) in tomato plants along with the coinoculation of a fungal pathogen (Chun and Chandrasekaran, 2019). CS application to plants aggregate around the pathogen penetration sites creating a physical barrier and avoids pathogen entry and colonization, stimulation of ROS such as $\mathrm{H}_{2} \mathrm{O}_{2}$, and accumulation of PR proteins such as chitinase, that induce the formation and accumulation of phenolic compounds such as phytoalexins, which in turn promotes lignification, inhibits the action of proteinase and activates peroxidase, SOD and CAT enzymes (Ali et al., 2014). These results indicated that SOD and CAT potentially protect plants against different oxidative stresses.

The induced systemic resistance is triggered by some bacteria and fungi and requires jasmonic acid (JA) and eth- 
ylene (ET). Differently, the SAR requires SA, exogenously applied or endogenously produced. The non-expression of pathogenesis-related genes $1(N P R l)$ in the cytosol regulates the cross-talk pathways of salicylate and jasmonate (Spoel et al., 2003). Bacillus cereus AR156 triggered the induction of the JA/ET-signaling pathway with the expression of NPR1 in Arabidopsis to Botrytis cinerea (Nie et al., 2017). Interestingly, another study reported that SAR induction by AR156 required NPR1 and SA-signaling pathway (Niu et al., 2016). For this, Wu et al. (2012) suggested that Arabidopsis NPR1 binds SA through cysteines ${ }^{521 / 529}$ via copper. Mou et al. (2003) reported that SAR is activated via NPRI-PRI and SAR activating mechanism. In our study, the results in Fig. 3A, CS and PCS have induced the expression of NPR 1 over the control plants. However, NPR1 expression was up-regulated in CS and PCS treated chili pepper, compared to untreated ones. This could indicate the CS and PCS efficacy against CMV by triggering SAR-related defense responses in chili pepper plants. On the contrary at a low-level concentration $(50 \mathrm{mg} / \mathrm{l})$ of CS oligosaccharide treatment induced the SA-signaling pathway in Arabidopsis to TMV infection was reported by Jia et al. (2016). Interestingly, these results are correlated and also JA levels were increased in the tomato plants treated with the CS oligosaccharide reported by Doares et al. (1995).

The effect of foliar spray with CS on the level of jasmonates and abscisic acid (ABA) and their responsive genes was determined in roots of mycorrhizal and nonmycorrhizal plants at a late stage of the symbiosis ( 9 weeks after inoculation). Quantification of ABA showed that treatment with CS did not affect significantly the level of ABA in mycorrhizal and non-mycorrhizal roots. However, the expression of the 9-cis-epoxycarotenoid dioxygenase gene (NCED1), a gene encoding one of the ABA-biosynthetic enzymes, showed different results. The expression of NCED1 increased with increasing concentrations of CS. The transcript accumulation of NCED1 was significantly increased in roots of non-mycorrhizal plants treated with 1 $\mathrm{mg} / \mathrm{ml}$ of CS. In this study the results are in the way with the study of other researchers, foliar spraying of CS and PCS materials inhibited CMV, PMMoV accumulation and induced the expression of defense genes in the chili pepper plants (Colson et al., 2010; Rendina et al., 2019).

\section{Conflicts of Interest}

No potential conflict of interest relevant to this article was reported.

\section{Acknowledgments}

This work was supported by a grant from the Basic Research Program (PJ01431803) of the National Institute of Horticultural and Herbal Science, Rural Development Administration, Republic of Korea. The authors are thankful to Dr. M.N. Prabhakar, Dept. of Mechanical Engineering, Changwon National University, Changwon, South Korea, for providing the CS and PCS materials.

\section{Electronic Supplementary Material}

Supplementary materials are available at The Plant Pathology Journal website (http://www.ppjonline.org/).

\section{References}

Adams, M. J., Antoniw, J. F. and Kreuze, J. 2009. Virgaviridae: a new family of rod-shaped plant viruses. Arch. Virol. 154:1967-1972.

Ali, A., Zahid, N., Manickam, S., Siddiqui, Y., Alderson, P. G. and Maqbool, M. 2014. Induction of lignin and pathogenesisrelated proteins in dragon fruit plants in response to submicron chitosan dispersions. Crop Prot. 63:83-88.

Anonymous. 2006. ICTVdb Management. 00.071.0.01.007. Pepper mild mottle virus. In: ICTVdb - The Universal Virus Database, version 4, ed. by C. Büchen-Osmond. Columbia University, New York, USA.

Chirkov, S. N., Il'ina, A. V., Surgucheva, N. A., Letunova, E. V., Varitsev, Y. A., Tatarinova, N. Y. and Varlamov, V. P. 2001. Effect of chitosan on systemic viral infection and some defense responses on potato plants. Russ. J. Plant Physiol. 48:774-779.

Cho, J. D., Kim, J. S., Lee, S. H., Choi, G. S. and Chung, B. N. 2007. Viruses and symptoms on peppers, and their infection types in Korea. Res. Plant Dis. 13:75-81 (in Korean).

Choi, G. S., Kim, J. H., Lee, D. H., Kim, J. S. and Ryu, K. H. 2005. Occurrence and distribution of viruses infecting pepper in Korea. Plant Pathol. J. 21:258-261.

Choi, G.-S., Kwon, S.-J., Choi, S.-K., Cho, I.-S. and Yoon, J.-Y. 2015. Characteristics of cucumber mosaic virus-GTN and resistance evaluation of chilli pepper cultivars to two cucumber mosaic virus isolates. Res. Plant Dis. 21:99-102 (in Korean).

Chun, S.-C. and Chandrasekaran, M. 2019. Chitosan and chitosan nanoparticles induced expression of pathogenesis-related proteins genes enhance biotic stress tolerance in tomato. Int. J. Biol. Macromol. 125:948-954.

Colson, P., Richet, H., Desnues, C., Balique, F., Moal, V., Grob, J.-J., Berbis, P., Lecoq, H., Harlé, J.-R., Berland, Y. and Raoult, D. 2010. Pepper mild mottle virus, a plant virus associated with specific immune responses, fever, abdominal pains, and pruritus in humans. PLOS ONE 5:e10041.

Damalas, C. A. and Koutroubas, S. D. 2016. Farmers' exposure 
to pesticides: toxicity types and ways of prevention. Toxics 4:1.

Doares, S. H., Syrovets, T., Weiler, E. W. and Ryan, C. A. 1995. Oligogalacturonides and chitosan activate plant defensive genes through the octadecanoid pathway. Proc. Natl. Acad. Sci. U. S. A. 92:4095-4098.

Elsharkawy, M. M., Shimizu, M., Takahashi, H. and Hyakumachi, M. 2012. Induction of systemic resistance against cucumber mosaic virus by Penicillium simplicissimum GP17-2 in Arabidopsis and tobacco. Plant Pathol. 61:964-976.

Feliziani, E., Landi, L. and Romanazzi, G. 2015. Preharvest treatments with chitosan and other alternatives to conventional fungicides to control postharvest decay of strawberry. Carbohydr. Polym. 132:111-117.

Hassan, O. and Chang, T. 2017. Chitosan for eco-friendly control of plant disease. Asian J. Plant Pathol. 11:53-70.

Iriti, M. and Varoni, E. M. 2015. Chitosan-induced antiviral activity and innate immunity in plants. Environ. Sci. Pollut. Res. 22:2935-2944.

Jia, X., Meng, Q., Zeng, H., Wang, W. and Yin, H. 2016. Chitosan oligosaccharide induces resistance to tobacco mosaic virus in Arabidopsis via the salicylic acid-mediated signaling pathway. Sci. Rep. 6:26144.

Kim, J.-S., Lee, S.-H., Choi, H.-S., Kim, M.-K., Kwak, H.-R., Kim, J.-S., Nam, M., Cho, J.-D., Cho, I.-S. and Choi, G.-S. 2012. 2007-2011 Characteristics of plant virus infections on crop samples submitted from agricultural places. Res. Plant Dis. 18:277-289 (in Korean).

Kumaraswamy, R. V., Kumari, S., Choudhary, R. C., Pal, A., Raliya, R., Biswas, P. and Saharan, V. 2018. Engineered chitosan based nanomaterials: bioactivities, mechanisms and perspectives in plant protection and growth. Int. J. Biol. Macromol. 113: 494-506.

Kwon, S.-J., Cho, I.-S., Yoon, J.-Y. and Chung, B.-N. 2018. Incidence and occurrence pattern of viruses on peppers growing in fields in Korea. Res. Plant Dis. 24:66-74 (in Korean).

Lee, J. H., Hong, J. S., Ju, H. J. and Park, D. H. 2015. Occurrence of viral disease in the field- cultivated pepper in Korea from 2006 to 2010. Korean J. Org. Agric. 23:123-131.

Lee, S. W., Heinz, R., Robb, J. and Nazar, R. N. 1994. Differential utilization of alternative initiation sites in a plant defense gene responding to environmental stimuli. Eur. J. Biochem. 226:109-114.

Liu, D., Jiao, S., Cheng, G., Li, X., Pei, Z., Pei, Y., Yin, H. and $\mathrm{Du}, \mathrm{Y}$. 2018. Identification of chitosan oligosaccharides binding proteins from the plasma membrane of wheat leaf cell. Int. J. Biol. Macromol. 111:1083-1090.

Liu, H., Du, Y., Wang, X. and Sun, L. 2004. Chitosan kills bacteria through cell membrane damage. Inter. J. Food Microbiol. 95:147-155.

Lustriane, C., Dwivany, F. M., Suendo, V. and Reza, M. 2018. Effect of chitosan and chitosan-nanoparticles on post-harvest quality of banana fruits. J. Plant Biotechnol. 45:36-44.

Malerba, M. and Cerana, R. 2016. Chitosan effects on plant sys- tems. Int. J. Mol. Sci. 17:996.

Mejía-Teniente, L., de Dalia Duran-Flores, F., Chapa-Oliver, A. M., Torres-Pacheco, I., Cruz-Hernandez, A., González-Chavira, M. M., Ocampo-Veláaquez, R. V. and Guevara González, R. G. 2013. Oxidative and molecular responses in Capsicum annuum L. after hydrogen peroxide, salicylic acid and chitosan foliar applications. Int. J. Mol. Sci. 14:10178-10196.

Mou, Z., Fan, W. and Dong, X. 2003. Inducers of plant systemic acquired resistance regulate NPR1 function through redox changes. Cell 113:935-944.

Nagorskaya, V., Reunov, A., Lapshina, L., Davydova, V. and Yermak, I. 2014. Effect of chitosan on tobacco mosaic virus (TMV) accumulation, hydrolase activity, and morphological abnormalities of the viral particles in leaves of N. tabacum L. Samsun. Virol. Sin. 29:250-256.

Nie, P., Li, X., Wang, S., Guo, J., Zhao, H. and Niu, D. 2017. Induced systemic resistance against Botrytis cinerea by $\mathrm{Ba}$ cillus cereus AR156 through a JA/ET- and NPR1-dependent signaling pathway and activates PAMP-triggered immunity in Arabidopsis. Front. Plant Sci. 8:238.

Niu, D., Wang, X., Wang, Y., Song, X., Wang, J., Guo, J. and Zhao, H. 2016. Bacillus cereus AR156 activates PAMP-triggered immunity and induces a systemic acquired resistance through a NPR1- and SA-dependent signaling pathway. Biochem. Biophys. Res. Commun. 469:120-125.

Pandey, V. P., Awasthi, M., Singh, S., Tiwari, S. and Dwivedi, U. N. 2017. A comprehensive review on function and application of plant peroxidases. Biochem. Anal. Biochem. 6:308.

Palukaitis, P. and García-Arenal, F. 2003. Cucumoviruses. Adv. Virus Res. 62:241-323.

Petutschnig, E. K., Jones, A. M. E., Serazetdinova, L., Lipka, U. and Lipka, V. 2010. The lysin motif receptor-like kinase (LysM-RLK) CERK1 is a major chitin-binding protein in Arabidopsis thaliana and subject to chitin-induced phosphorylation. J. Biol. Chem. 285:28902-28911.

Povero, G., Loreti, E., Pucciariello, C., Santaniello, A., Di Tommaso, D., Di Tommaso, G., Kapetis, D., Zolezzi, F., Piaggesi, A. and Perata, P. 2011. Transcript profiling of chitosan-treated Arabidopsis seedlings. J. Plant Res. 124:619-629.

Pratiwi, A., Dwivany, F. M., Larasati, D., Islamia, H. C. and Martien, R. 2015. Effect of chitosan coating and bamboo FSC (fruit storage chamber) to expand banana shelf life. AIP Conf. Proc. 1677:100005.

Qin, F., Shinozaki, K. and Yamaguchi-Shinozaki, K. 2011. Achievements and challenges in understanding plant abiotic stress responses and tolerance. Plant Cell Physiol. 52:15691582.

Rendina, N., Nuzzaci, M., Scopa, A., Cyuypers, A. and Sofo, A. 2019. Chitosan-elicited defense response in cucumber mosaic virus (CMV)-infected tomato plants. J. Plant Physiol. 234235:9-17.

Rohini, N. and Lakshmanan, V. 2017. Evaluation studies of hot pepper hybrids (Capsicum annum L.) for yield and quality characters. Electron. J. Plant Breed. 8:643-651. 
Shahrajabian, M. H., Chaski, C., Polyzos, N., Tzortzakis, N. and Petropoulos, S. A. 2021. Sustainable agriculture systems in vegetable production using chitin chitosan as plant biostimulants. Biomolecules 11:819.

Sharif, R., Mujtaba, M., Ur Rahman, M., Shalmani, A., Ahmad, H., Anwar, T., Tianchan, D. and Wang, X. 2018. The multifunctional role of chitosan in horticultural crops: a review. Molecules 23:872.

Sivakumar, D., Bill, M., Korsten, L. and Thompson, K. 2016. Integrated application of chitosan coating with different postharvest treatments in the control of postharvest decay and maintenance of overall fruit quality. In: Chitosan in the preservation of agricultural commodities, eds. by S. BautistaBanos, G. Romanazzi and A. Jimenez-Aparicio, pp. 127-153. Academic Press, Cambridge, MA, USA.

Spoel, S. H., Koornneef, A., Claessens, S. M. C., Korzelius, J. P., Van Pelt, J. A., Mueller, M. J., Buchala, A. J., Métraux, J.-P., Brown, R., Kazan, K., Van Loon, L. C., Dong, X. and Pieterse, C. M. J. 2003. NPR1 modulates cross-talk between salicylate- and jasmonate-dependent defense pathways through a novel function in the cytosol. Plant Cell 15:760-770.

Statistics Korea. 2020. Production of chili pepper, sesame and highland potatoes in 2020. URL http://kostat.go.kr [1 September 2021].

Sudhakar, N., Nagendra-Prasad, D., Mohan, N. and Murugesan, K. 2007. Induction of systemic resistance in Lycopersicon esculentum cv. PKM1 (tomato) against cucumber mosaic virus by using ozone. J. Virol. Methods 139:71-77.

Vitti, A., Pellegrini, E., Nali, C., Lovelli, S., Sofo, A., Valerio, M., Scopa, A. and Nuzzaci, M. 2016. Trichoderma harzianum $\mathrm{T}-22$ induces systemic resistance in tomato infected by cu- cumber mosaic virus. Front. Plant Sci. 7:1520.

Voss-Fels, K. and Snowdon, R. J. 2016. Understanding and utilizing crop genome diversity via high-resolution genotyping. Plant Biotechnol. J. 14:1086-1094.

Wetter, C., Conti, M., Altschuh, D., Tabillion, R. and van Regenmortel, M. H. V. 1984. Pepper mild mottle virus, a Tobamovirus infecting pepper cultivars in Sicily. Phytopathology 74:405-410.

Wu, Y., Zhang, D., Chu, J. Y., Boyle, P., Wang, Y., Brindle, I. D., De Luca, V. and Despres, C. 2012. The Arabidopsis NPR1 protein is a receptor for the plant defense hormone salicylic acid. Cell Rep. 1:639-647.

Xing, K., Zhu, X., Peng, X. and Qin, S. 2015. Chitosan antimicrobial and eliciting properties for pest control in agriculture: a review. Agron. Sustain. Dev. 35:569-588.

Yin, H. and Du, Y. 2010. Mechanism and application of chitin/ chitosan and their derivatives in plant protection. In: Chitin, chitosan, oligosaccharides and their derivatives, ed. by S.-K. Kim, pp. 605-617. CRC Press, Boca Raton, FL, USA.

Yoon, J.-Y., Gangireddygari, V. S. R., Cho, I.-S., Chung, B.-N., Yoon, B.-D. and Choi, S.-K. 2021. Effects of $\beta$-glucans from Aureobasidium pullulans on cucumber mosaic virus infection in chili pepper. Res. Plant Dis. 27:17-23.

Yoon, J. Y., Paluakaitis, P. and Choi, S. K. 2019. Host range. In: Cucumber mosaic virus, eds. by P. Palukaitis and F. GarciaArenal, pp. 15-18. American Phytopathological Society, St. Paul, MN, USA.

Zhang, D., Wang, H., Hu, Y. and Liu, Y. 2015. Chitosan controls postharvest decay on cherry tomato fruit possibly via the mitogen-activated protein kinase signaling pathway. J. Agric. Food Chem. 63:7399-7404. 